Rok XV (2020) | 1 (29) | S. 251-264

https://doi.org/10.12797/LV.15.2020.29.16

Norbert Ostrowski $\odot$

Uniwersytet Jagielloński, Kraków

norbert.ostrowski@uj.edu.pl

\title{
DLACZEGO BAŁTOWIE I SŁOWIANIE LICZYLI POKREWIEŃSTWO W KOLANACH, CZYLI O ETYMOLOGII SŁOW. KOLĚNO 'KOLANO; RÓD' I LIT. KẼLIS 'KOLANO; RÓD'
}

Słowa klucze: etymologia, języki bałtyckie i słowiańskie, indoeuropeistyka, prawo zwyczajowe Keywords: etymology, Baltic and Slavic languages, Indoeuropean linguistics, customary law

\section{Wstęp}

Jest rzeczą dobrze znaną etymologom, że w językach bałtyckich i słowiańskich wyraz oznaczający 'kolano' ma również znaczenie 'ród, pokolenie', por. scs. kolěno 'kolano; ród' i lit. kẽlis 'kolano; kolanko na słomce; ród; stopień pokrewieństwa' w przykładzie z Punktów kazań (1629) Konstantego Szyrwida: dwilika kialu aba giminiu Izraelo (SP I: 5) 'dwanaśćie pokolenia Israelskiego' (dosł. 'dwanaście pokoleń albo rodów Izraela'). Stan ten zaświadczony jest również w polszczyźnie w derywacie pokolenie - a więc to, co następuje po kolanie. Artykuł stawia sobie dwa cele:

1. Wyjaśnić genezę polisemii słow. kolěno 'kolano; ród’ i lit. kẽlis 'kolano; ród; stopień pokrewieństwa'. Temu zagadnieniu poświęcona jest część 2, w której będę bronił dwóch tez:

a) wyrazy słowiańskie i bałtyckie funkcjonowały jako terminy z zakresu prawa zwyczajowego i były związane z dziedziczeniem (Białuński 2014);

b) punktem wyjścia rozwoju semantycznego było znaczenie 'przegub, staw', co tłumaczy związek słow. kolěno 'kolano; ród' z psłow. ${ }^{\star} k e l-n \breve{u}->{ }^{*}$ čelnŭ- > psłow. ${ }^{*}$ čel-nŭ- 'przegub, staw' (por. pol. członki ciała). Formy słowiańskie i bałtyckie stoją w związku etymologicznym z ide. ${ }^{*} k^{w} e l h_{1}$ - 'obracać (się)'. 
2. Opisać od strony diachronicznej budowę słow. kolěno 'kolano; ród' i lit. kẽlis 'kolano; ród', czyli wyjaśnić funkcje dodanych sufiksów oraz wskazać podstawę słowotwórczą derywatów. W części 3 bronię dwóch tez:

a) słow. kolěno 'kolano; ród' jest z pochodzenia derywatem przymiotnikowym z sufiksem posesywnym -ěn- *'należący do obracającej się części ciała, dosł. kołowy’ od podstawy ${ }^{\star} k^{w} o_{l} h_{1}$ - (por. stgr. $\pi$ óloc 'oś', scs. kolo, -ese 'koło').

b) lit. kẽlis (2) / (dial.) kelỹs (2) 'kolano; kolanko u słomki; ród' i łot. celis 'kolano' to stare przymiotniki z sufiksem posesywnym ${ }^{*}$-ija- od rzeczownika pbałt. ${ }^{*} k e l-a$-, por. stpr. kelan 'koło', łot. duceles 'dwukółka' i łot. cęls 'warstwa nici na kłębku' < $<{ }^{\star}$ kelas.

\section{0 polisemii słow. kolěno 'kolano; pokolenie' i lit. kẽlis 'kolano; ród' oraz jej przyczynach}

Francuski celtolog Joseph Loth w swoich dwóch artykułach $(1917-1919,1923)$ zwrócił uwagę, że w kilku językach ide. wyraz oznaczający ‘kolano’ ma również znaczenie 'pokolenie, ród'. Przykłady tej polisemii odnajdujemy w językach germańskich, słowiańskich i bałtyckich, ale jej ślady widoczne są również w średniowiecznej łacinie oraz w siedemnastowiecznym języku irlandzkim. Zacznijmy od prezentacji materiału germańskiego. An Anglo-Saxon Dictionary Boswortha i Tollera (1898) podaje:

- cneów (neutrum): 1) 'a knee', 2) 'a generation': In ðœere peóde awóc his ðœet pridde cneów 'in that nation rose the third generation from him', a także kilka złożeń, m.in.:

- cneó-mógas 'relations of the same sex or the same generation; consanguinei': mid ðám cneómágum 'with his kinsmen';

- cneów-sib 'a race, generation; generatio': Cende cneówsibbe cénra manna 'he begot a race of brave men'.

W Wörterbuch zur altnordischen Prosaliteratur Waltera Baetkego (2006) pod hasłem kné znajdujemy trzy znaczenia: '1) kolano, 2) część drewniana statku, 3) stopień pokrewieństwa'. Za Adrianem Părvulescu (1997: 74) można jeszcze przytoczyć stfr. knī, knē, kniū 'kolano; krewny' oraz hol. even knie 'na tym samym stopniu pokrewieństwa'. Wyrazy germańskie kontynuują, z pewnymi przekształceniami formalnymi (jako tzw. typ proterokinetyczny), akrostatyczny rzeczownik ide. ${ }^{*}$ g'onu $^{\prime}$ 'kolano' (por. stgr. yóvv 'kolano', łac. genu). A zatem znaczenia 'stopień pokrewieństwa, pokolenie' są innowacją. Podobną innowację obserwujemy w irl. glúin 'kolano', wyrazie odziedziczonym z epoki indoeuropejskiej, a od XVII w. zaświadczonym również w znaczeniu 'pokolenie'. Părvulescu (ibid.: 75) zwrócił uwagę na podobne zmiany w łacinie średniowiecznej oraz w dialektach rumuńskich. Słownik Jana Niermeyera (1976) odnotowuje łac. genu 'kolano' tylko w znaczeniu 'degree in 
relationship', natomiast jako 'kolano' zaświadczone jest w tym słowniku dawne deminutivum geniculum. Jako drugie znaczenie geniculum Niermeyer podaje 'degree in relationship'. Z kolei słownik średniowiecznej łaciny Alberta Blaise’a (1975) pod hasłem genu wymienia zarówno 'kolano', jak i 'stopień pokrewieństwa', np. in tertio genu, in quintum genu. Uderzająca jest zbieżność fraz in tertio genu z odpowiednimi frazami litewskimi, o czym dalej. Za Părvulescu dodajmy także, że arum. genunchi (< łac. geniculum) znaczy 'knee; lineage, tribe, people'.

Nie ma wątpliwości, że we wszystkich wymienionych przykładach znaczenie 'stopień pokrewieństwa' jest innowacją. Aby ją wyjaśnić, Loth postawił dwie hipotezy. Według pierwszej chodziło o zwyczaj uznania niemowlęcia za należące do rodu poprzez wzięcie go na kolana. Zwyczaj ten jest bardzo stary, znany zarówno wśród ludów indoeuropejskich, jak i w świecie semickim. Na poparcie tej tezy Loth cytował akad. tarbit birkiya 'zaadoptowany syn' (dosł. 'kolano-osesek'), stirl. glún-daltae 'infant of the knee', stisl. kné-setningr 'Pflegesohn'. Można tu jeszcze dodać stisl. kné-setja we frazie kné-setja barn'sich e. Kind aufs Knie setzen zum Zeichen, daß man es als Pflegekind annimmt' (Baetke 2006: 331-2). Z kolei Émile Benveniste (1927) przy toczył sogd. $z$ 'nwk $z^{\prime} t k$ 'fils héritier' ( $z^{\prime} n w k$ 'kolano', $z^{\prime} t k$ 'syn'). Părvulescu (1997: 76, 77 $\left.{ }^{16}\right)$ za Lothem przypomniał i omówił fragmenty z Księgi Rodzaju (30, 3; 48,12 i 50, 23). Do tych przykładów możemy dodać werset z Księgi Hioba $(3,12)$ : „Po cóż mnie przyjęły kolana, a piersi podały mi pokarm?”. Cenne są omówione przez Părvulescu fragmenty z Iliady (9, 449-456) i Odysei (19, 399-412). Nowo narodzony Odyseusz został położony na kolanach dziadka (sic!), Autolykosa, ojca matki Odyseusza, i to dziadek (po kądzieli) nadał mu imię. Părvulescu przytoczył także inne przykłady tego zwyczaju z późniejszej greki (Demostenes, Ajschines) oraz wcześniejsze z języka hetyckiego. Nie udało mi się stwierdzić, czy na obszarze Słowiańszczyzny znany był podobny obyczaj, ale atrakcyjnie w tym kontekście brzmi tradycyjna etymologia słow. ${ }^{*}$ čelověkr < ${ }^{*} k e l a-v a i k-a-$ (np. SPsł II: 132). Zgodnie z nią jest to złożenie z čel- w pierwszym członie, dla którego przytacza się jako comparandum psłow. *čelěds 'ród, rodzina', a którego pierwotne znaczenie widoczne jest jeszcze w zapożyczeniu węg. család 'ród, rodzina'. Ponieważ derywaty na -éds były to pierwotnie abstracta tworzone od przymiotników, np. *črnéds 'czerń' od ‘črnz 'czarny' (Sławski 1974: 64), to na podstawie psłow. *čelědo możemy odtworzyć podstawę przymiotnikową * čel-, która pod względem stopnia apofonicznego i funkcji zgadza się z lit. kẽlis 'kolano; ród', z pochodzenia starym przymiotnikiem (zob. część 3). Drugi człon złożenia *čelověk odpowiada lit. vaîkas (4) 'dziecko' (stpr. waix 'młodzieniec;

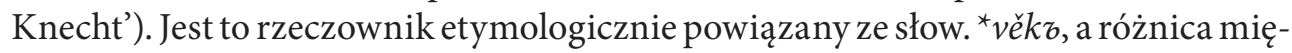
dzy lit. vaĩkas (4) 'dziecko’ a słow. ${ }^{*}$ ěk : barytona, gdzie forma litewska kontynuuje oksytoniczne nomen agentis ${ }^{\star}$ woyk-ó- 'ten, który działa' wobec barytonicznego nomen actionis *wóyk-o- 'działanie' > > słow. ${ }^{*}$ vẽ̃kr > s-chorw. vïjek (Kabašinskaite 2014: 94). Zatem psłow. čelo-věkr znaczyłby pierwotnie *'młody osobnik należący do rodu’ i byłby to rezultat uniwerbi- 
zacji frazy, która zachowała się we wspomnianym już stisl. kné-setja barn 'sich e. Kind aufs Knie setzen zum Zeichen, daß man es als Pflegekind annimmt' (Baetke 2006: 331-2).

Druga zaproponowana przez Lotha hipoteza nawiązuje do wyobrażenia rodu jako drzewa (por. stirl. gabla fine 'pokolenie', dosł. 'gałąź rodziny' - gabla 'gałąź, fine 'rodzina, ród'). W tym ujęciu chodziłoby o metaforyczny sposób liczenia pokoleń według kolanek na łodydze i odrostów rocznych rośliny. W staroislandzkiej Sadze o Njallu pojawia się zagadkowe złożenie kné-runnr (m.) 'lineage, kinship, degree in descent', gdzie drugim członem złożenia jest rzeczownik runnr (-s, -ar), m. 'krzak'. Ciekawej paraleli dostarcza stind. vamsśa 'ród, dynastia; trzcina bambusowa; belka poprzeczna w konstrukcji dachu’. Jak jednak zauważa Părvulescu, na przeszkodzie uznaniu tej hipotezy stoi fakt, że w językach germańskich mamy zaświadczone znaczenia 'kolano' oraz 'ród, pokolenie', ale brakuje koniecznego etapu pośredniego 'kolanko na łodydze'. Wprawdzie stgr. yóvv i łac. genu znaczą zarówno ‘kolano', jak i 'kolanko na słomce', ale akurat w obu językach nie liczono rodu w kolanach. Sam Părvulescu, chcąc wyjaśnić związek między łac. poples 'kolano' i populus 'lud', opowiedział się za zmianą znaczeniową 'wiązać, łączyć' > 'kolano' > 'ród, pokolenie'. Czyli według Părvulescu mamy do czynienia ze zmianą, w której znaczenie 'ród, pokolenie' rozwinęło się bezpośrednio ze znaczenia 'kolano'. Jest to jednak pójście na skróty, ponieważ nadal nie wiemy, w jaki sposób mogło dojść do zmiany metaforycznej 'kolano' > 'ród, pokolenie'. W przypadku języków bałtyckich i słowiańskich do wyjaśnienia polisemii 'kolano; ród, pokolenie’ z pomocą przychodzi prawo zwyczajowe, którego opis zachował się w języku średnio-dolno-niemieckim. Zacznijmy jednak od prezentacji materiału litewskiego.

Przykład stlit. kẽlis (2) 'ród' z Punktów kazań (1629) Konstantego Szyrwida (wschodnia Litwa) przytoczyłem na wstępie. W Postylli (1599) Mikołaja Daukszy (okolice Kiejdan; środkowa Litwa), czytamy:

idąnt' niékas neweftús nei tekétus artimiéii / nęt' ik kętwirtám kęlui (DP 470, 32-33) = 'żeby nikt nie poymował w Małżeństwo powinowátych swych / áż do czwartego pokolenia' (Postylla Mnieysza Jakuba Wujka).

Z tego samego obszaru Litwy pochodzą materiały zebrane i opublikowane w 1931 r. przez Mikalojusa Katkusa. Dokładniej chodzi o obszar dorzecza rzeczki Šušvè, prawego dopływu Niewiaży (okolice miasteczka Josvainiai, pol. Jaswojnie):

Kas tai keliai broliai: broliu vaikai keliai, ju vaikai - antri keliai (Katkus 1931: 125) 'Kim są rodzeni bracia (dosł. kolanowi bracia): dzieci braci to pierwsze pokolenie (dosł. kolana), ich dzieci - drugie pokolenie (dosł. drugie kolana)'.

W zdaniu tym na uwagę zasługuje fraza keliai broliai (dosł.) 'kolanowi bracia', gdzie keliai występuje w szyku atrybutywnym do rzeczownika broliai 'bracia'. Jest to ważny argument składniowy przemawiający za interpretacją kẽlis jako starego 
przymiotnika. Do tego zagadnienia powrócę w części 3. Kolejne przykłady z pracy Katkusa:

Tai mes su Tamsta, Josaitiene, vienas trečius, kitas ketvirtus kelius kertame (ibid.: 127) 'To my z Panią, Josaitiene, jeden stanowi trzecie, a drugi czwarte pokolenie (dosł. tniemy czwarte kolana)'.

Ir dabar sakoma: broliai pirmus kelius kerta, ju vaikai antrus kelius kerta (ibid.) 'I teraz mówi się: bracia stanowią pierwsze pokolenie (dosł. tną pierwsze kolana), ich dzieci są drugim pokoleniem (dosł. tną drugie kolana)'.

Brakuje podobnych śladów polisemii 'kolano; pokrewieństwo' w języku łotewskim, ale interesującego materiału dostarcza cytowany przez Grzegorza Białuńskiego (2014: 191) fragment umowy z 1267 r. między zakonem krzyżackim a Kurszami:

Ein jegelike erve solen si erheven in dem vijrden knie, also doch dat sin here in sime rechte en genen schade neme

'Każdy spadek winni oni pobierać w czwartym kręgu spadkobierców (dosł. w czwartym kolanie), tak samo razem podejmuje się każdą szkodęe.

Wynika z niego, że chodzi o różne grupy spadkobierców żyjących w tym samym czasie. Jest rzeczą uderzającą, że przeszło 250 lat później w Postylli Daukszy również jest mowa o czwartym kolanie. Rodzi się pytanie: kto wchodził w skład czwartego kolana oraz kolan wcześniejszych?

Różne kręgi spadkobierców były znane w prawie rzymskim. Institutiones (533) Justyniana wyróżniały sześć stopni (łac. gradus) pokrewieństwa, ale kluczowy dla nas jest przytoczony przez Białuńskiego (ibid.: 189) fragment Zwierciadła saskiego (ok. 1235) (Repgow 1861: I, 3, §3):

$\mathrm{Nu}$ merke wie ok, war de sibbe beginne unde war se lende. In deme hovede is besceiden man unde wif to stande, die elike unde echtlike to samene komen sin. In des halses lede die kindere, die ane tveinge vader unde muder geboren sin. Is dar tveinge an, die ne mogen an eine lede nicht bestan unde scricket an ein ander let. Nemet ok tvene brudere tvo sustere, unde de dridde bruder en vremede wif, ire kindere sint doch gelike na, ire iewelk des anderen erve to nemene, of se evenburdich sint. Ungetveider bruder kindere de stat an deme lede, dar sculderen unde arm to samene gat; als dut die suster kindere. Dit is de irste sibbe tale, die man to magen rekenet: bruder kindere unde suster kindere. In dem ellenbogen stat die andere. In dem lede der hant de dridde. In dem irsten lede des middelsten vingeres de vierde. In dem anderen lede de vefte. In dem dridden lede des vingeres de seste. In dem seveden stat ein nagel unde nicht ein let, dar umme lent dar de sibbe, unde hetet nagel mage. Die tvischen deme nagele unde deme hovede sik to der sibbe gestuppen mogen an geliker stat, de nemet dat erve gelike. De sik naer to der sibbe gestuppen mach, de nimt dat erve to voren. De sibbe lent in dem seveden erve to nemene. 
Polskie tłumaczenie (zmodyfikowane przez Białuńskiego) podaję za Historia państwa i prawa (Gulczyński i in. 2002: 114):

Teraz zważmy, gdzie ród się zaczyna i gdzie się kończy. Mąż i żona, którzy połączyli się małżeństwem w sposób zgodny z prawem, przeznaczeni są do zajmowania miejsca głowy. W miejscu kolanka szyi stoją dzieci, które są rodzeństwem i wszystkie pochodzą od tegoż ojca i tej samej matki. Rodzeństwo przyrodnie nie może do tego stopnia należeć i dlatego znajduje się na miejscu innego kolanka. Dalej, gdy dwaj bracia pojmą dwie siostry, a trzeci brat obcą niewiastę, to dzieci ich wszystkich równie są uprawnione do dziedziczenia jedno po drugim, o ile są tego samego stanu. Dzieci rodzonych braci znajdują się w tym kolanku, gdzie ramiona łączą się z ręką. Podobnie i dzieci sióstr. Jest to pierwszy stopień pokrewieństwa, który zalicza się do krewnych: dzieci braci i sióstr. Na łokciu znajduje się drugi stopień pokrewieństwa rodowego, na kolanku nadgarstka trzeci, na pierwszym kolanku środkowego palca czwarty, na drugim kolanku piąty, a na trzecim kolanku szósty. Na siódmym znajduje się paznokieć, a nie kolanko, dlatego kończy się tam rod i nazywa się ich krewnymi paznokciowymi. Ci pomiędzy paznokciem i głową, którzy są w rodzie na tym samym stopniu, biorą dziedzictwo w równej części. Kto liczy się jako bliższy stopniem, pierwszy bierze spadek. Przy dziedziczeniu ród kończy się na siódmym stopniu.

W tłumaczeniu polskim Białuński użył słowa kolano, chociaż w tekście dolnoniemieckim nigdzie nie występuje Knie, lecz lede i jego warianty. Wymienia je Gerhard Köbler (2014) w swoim słowniku dolnoniemieckim:

lit (2), lēt, let, lyed, leit, leet, lēde, mnd., N.: nhd. Glied, Körperglied, Kettenglied, Teil zwischen zwei Gelenken, Glied des Pflanzenhalms, Handgelenk, Fußgelenk, Armgelenk [...]: nhd. „eines Gliedes lang“ (als Maß der Wunde); [...]: nhd. „Glieder“, Extremitäten, Gliedgelenke als Zusammenhalt des Körpers; R.: gelenke an lēden: nhd. körperlich gelenkig; [...]; R.: lit des armes: nhd. „Glied des Armes“, Ellenbogengelenk; [...] R.: viffte lit: nhd. „fünftes Glied“, fünfte Generation; [...], Schultergelenk, Armgelenk und Handgelenk und Mittelfingergelenk sind Symbole des Verwandtschaftsgrads (Schultergelenk entspricht der dritten Generation).

A zatem lede znaczy 'staw, przegub', ale również 'stopień pokrewieństwa'. Wyraz niemiecki zaświadczony jest już w starych językach germańskich, np. goc. lipus 'member, body part', a za prymarnym znaczeniem 'staw, przegub' przemawia stisl. liðr m. (temat na - $u$-) 'joint of the body'. Zapewne ze względu na świadectwo gockie Guus Kroonen (2013: 340) przyjmuje dla pgerm. ${ }^{*} l i p u$ pierwotne znaczenie 'member, body part', które jednak wydaje się wtórne wobec stisl. liðr 'joint of the body' i które można łatwo objaśnić jako rezultat metonimii, na co paraleli dostarczają języki bałtyckie i słowiańskie ${ }^{1}$.

1 Jak zwrócił uwagę Părvulescu (1997: 79), wymienione formy germańskie mogą stać w związku ze stisl. lið neutr. (temat na -a-) 'host, folk, people, family, household, troops; help, assistance’. 
W III Katechizmie staropruskim (1561), tłumaczonym przez Abla Willa z Enchiridionu Marcina Lutra, oraz w tekstach starolitewskich Jana Bretkuna (dawne Prusy Wschodnie) w znaczeniu 'pokolenie, ród' pojawiają się rzeczowniki o pierwotnym znaczeniu 'staw, część ciała' (łac. articulus). Zacznijmy od litewskiego rzeczownika squnarys 'staw, przegub; część ciała; pokolenie', który jest derywatem od sunerti 'łączyć splatając, wiążąc' (stlit. suiungiu / suneriu / sugłaudźiu 'złączam co / coniungo, copulo socio’ (SD 3: 546)). W przykładzie z 2 Księgi Królewskiej $(15,12)$ w tłumaczeniu Jana Bretkuna (koniec XVI w.) mamy zaświadczone sqnarys 'pokolenie':

Sèsis vaikai iki ketvirtos eilès (ketvirto sąnario) ant kréslo Izraelio (cyt. za LKŽ 12, 112)

'Dzieci twoje zasiadać będą na tronie Izraela aż do czwartego pokolenia'.

'Dir sollen Kinder ins vierte Glied sitzen auf dem Stuhl Israels' (Luther 1545).

Kolejny przykład to staropruski rzeczownik streipstan 'członki ciała; pokolenie', zachowany w III Katechizmie staropruskim (1561):

stpr. streipstan / niem. Glieder 'części ciała’:

Abel Will: As druwē / kai mien Deiws Teikūnus ast / sen wissans peergimmans / mennei kērmenan bhe Düsin ackins / àusins / bhe wissans streipstans (III 41, 2-4)

'Wierzę, że Bóg mnie stworzył razem ze wszystkimi istotami, moje ciało i duszę, oczy, uszy i wszystkie członki ciała'.

Luther: ich gleube / das mich Gott geschaffen hatt / sampt allen Creaturen / Mir Leyb vnd Seel / Augen Ohren / vnd alle Glieder.

stpr. streipstan / niem. Glieder 'pokolenie':

Abel Will: stans grīkans steisei tāwans kāimaluke ènstēimans malnijkans / ergi en tìrtin bhe ketwirtin streipstan (III 37, 14-16)

'Grzechy ojców przechodzą na dzieci aż do trzeciego i czwartego pokolenia'.

Luther: die suende der Vaeter heimsucht an den Kindern bis ins Dritte und Vierde gelied.

Odpowiednikiem etymologicznym stpr. streipstan jest lit. stráipsnis 'artykul', który w starolitewskim tłumaczeniu Biblii Jana Bretkuna znaczył 'część ciała; pokolenie’:

lit. stráipsnis 'członki, części ciała’:

Mana Strajpfnei man drab delei to regeghimo, bei nera manip newienos filos daugefni (BBDan 10, 16)

'Moje członki drżą mi na ten widok i nie ma we mnie więcej siły'. 
meine Gelenke beben mir über dem Gesicht, und ich habe keine Kraft mehr (Luther 1545).

lit. stráipsnis 'pokolenie’:

Nuog Abrahamo iki Davydo yra keturiolika straipsnių [giminių] (BBMt 1, 17)

'Od Abrahama do Dawida jest czternaście pokoleń'.

Alle Gelied von Abraham bis auff Dauid sind vierzehen gelied (Luther 1545).

Przytoczone przykłady bałtyckie 'staw, przegub; członki ciała; pokolenie’ rzucają światło na związek etymologiczny między słow. kolěno 'kolano' a psłow. ${ }^{\star} k e l-n \breve{u}->$ $>$ *čelnŭ- > pol. człon (por. 'członki ciała'), strus. člěnz 'część ciała' (Sreznevskij 1893: 1536). SPsł (II: 125) notuje dla słoweń. člèn następujące znaczenia: 'część składowa jakiejś całości; część palca między dwoma stawami; część łodygi między dwoma kolankami; dial. przegub nogi', a także 'staw, przegub; kostka, talus (kość skokowa)'. Z kolei dla chorw. člân m.in. 'staw, przegub, najczęściej: kostka u nogi, talus'. Różnicę znaczeń między kolěno 'kolano' a psłow. kel-nŭ- > čelnŭ- możemy łatwo wyjaśnić, wychodząc od 'staw, przegub' ('obracająca się część ciała') jako znaczenia pierwotnego.

Podsumowując tę część, możemy stwierdzić, że w trzech grupach językowych (bałtyckiej, germańskiej i słowiańskiej) obserwujemy polisemię 'staw, przegub; część ciała' oraz 'pokolenie, ród', a przyczyną jej powstania było prawo zwyczajowe, w którym do liczenia stopni pokrewieństwa w obrębie rodu używano części ciała od głowy do paznokcia palca środkowego. Jeśli przyjmiemy za pierwotne znaczenie 'staw, przegub’, wówczas nic nie stoi na przeszkodzie, aby słow. kolěno i lit. kẽlis powiązać etymologicznie z ide. ${ }^{*} k^{w} e l h_{1}$ - 'obracać (się)', jak to się zresztą przeważnie czyni w słownikach etymologicznych. Powstaje jednak pytanie, czy można bliżej określić budowę słow. kolěno i lit. kẽlis poprzez wskazanie podstawy słowotwórczej oraz funkcji użytych w derywacji sufiksów. Temu zagadnieniu poświęcona jest część 3 .

\section{Etymologia słow. kolěno i lit. kẽlis 'kolano; kolanko u słomki; ród'}

W części 2 wyjaśniłem związek znaczeniowy między ‘stopień pokrewieństwa' i ‘staw, przegub', a etymologicznie wiążą się one z ide. ${ }^{\star} k^{w} e l h_{1}-$ 'obracać (się)'. W tej części chcę odpowiedzieć na trzy pytania:

1. Jaką funkcję pełnił sufiks -ěn-?

2. Jak wyjaśnić stopień apofoniczny słow. kolěno?

3. Jak mają się do siebie pod względem budowy słowotwórczej słow. kolěno i lit. kêlis / kelỹs 'kolano; kolanko na słomce; ród, pokolenie’?

Sufiks -ěn- jest zaświadczony zarówno w językach bałtyckich, jak i słowiańskich. Służy on do derywacji denominatywów, a jego funkcją wspólną dla obu grup języko- 
wych jest wyrażanie przynależności, np. bratı / bratrı $\rightarrow$ brat-ěnz / bratr-ěnz 'bratanek; kuzyn; braciszek'; sestra $\rightarrow$ sestr-ènz 'siostrzeniec', lit. brólis 'brat' $\rightarrow$ brolénas 'bratanek', sesuõ / gen. sg. sesers 'siostra' $\rightarrow$ seserénas 'siostrzeniec' (Sławski 1974: 128-9). W języku łotewskim sufiks -ěn- nabrał sekundarnego znaczenia deminutywnego, np. łot. māsa 'siostra' $\rightarrow$ māsēna 'siostrzyczka' (Endzelin 1922: 221). Rozwój funkcjonalny 'przynależność' $\rightarrow$ 'deminutywność możemy prześledzić na przykładzie sufiksu -inn-. W swej pierwotnej funkcji przynależnościowej zaświadczony jest on m.in. w lit. káimas 'wieś' $\rightarrow$ kaimýnas 'sąsiad' < *'należący do jednej wsi', łac. vīcus 'uliczka, część miasta; wieś' $\rightarrow$ vīcīnus 'mieszkający w pobliżu; sąsiad', stind. grăma'wieś' $\rightarrow$ grāminna- 'mieszkaniec wsi'. Inne przykłady litewskie: brólis 'brat' : brolýnas 'bratanek'; sesuõ, -er̃s 'siostra' : seserýnas 'siostrzeniec'. Z tej funkcji rozwinęło się w litewskim znaczenie patronimiczne, np. Adõmas 'Adam' : Adomýnas 'syn Adama', Tùmas 'Tomasz' : Tumýnas, Jõnas 'Jan' : Jonýnas. Sufiks ten jest zaświadczony również w językach germańskich do tworzenia przymiotników o znaczeniu przynależności, np. stang. foederen 'ojcowski' (substantywizowany w goc. fadrein 'ród, pochodzenie' < $\left.{ }^{\star} f a d r-i n a-\right)$, stang. mēdren 'matczyny' (Casaretto 2004: 327 i n.), ale także w sekundarnej funkcji deminutywnej, np. stwysniem. geizzīn, goc. gaitein 'junger Ziegenbock' od germ. ${ }^{\star}$ gait- (Griepentrog 1995: 204 i n.; Casaretto 2004: 327 i n.).

Słow. kolěno to zatem derywat posesywny, pierwotnie stary przymiotnik, który stał $\mathrm{w}$ jednej frazie $\mathrm{z}$ bliżej nieokreślonym rzeczownikiem rodzaju nijakiego. Derywat z tym samym sufiksem odnajdujemy w litewskim kelénas 'rzepka kolanowa; kolano'. Jako podstawę derywacyjną dla kelénas 'rzepka kolanowa; kolano' litewski etymolog Vytautas Mažiulis (1993: 155-156) przyjął rzeczownik kel-a-n 'koło', zaświadczony w języku staropruskim. Jak spróbuję wykazać dalej, podobną derywację należy przyjąć dla słow. kolěno i lit. kẽlis / łot. celis 'kolano'. Podstawowym znaczeniem lit. kelénas jest 'rzepka kolanowa', a znaczenie 'kolano' jest wynikiem zmiany metonimicznej.

Kolejny problem stanowi stopień apofoniczny słow. kolěno. Zauważmy, że dodanie sufiksu -ěn- nie pociąga za sobą zmiany stopnia apofonicznego w derywacie. Inaczej mówiąc, derywaty z sufiksem -ěn- powtarzają stopień apofoniczny podstawy nominalnej, np. sestra $\rightarrow$ sestr-ěn 'siostrzeniec'. Z tego wynika, że kolěno musi być derywatem od jakiegoś rzeczownika na stopniu $o$. Istnienie takiego rzeczownika w prasłowiańszczyźnie możemy wnioskować na podstawie scs. kolo, kolese 'koło' (por. pol. pług koleśny, gw. kolesar 'kołodziej'). Jak wiadomo, derywaty z sufiksem -es- na późnym etapie rozwoju języka indoeuropejskiego charakteryzowały się uogólnionym stopniem pełnym rdzenia i sufiksu, co widać $\mathrm{w}$ scs. nebo, nebese <

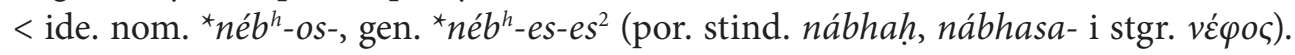

2 Uogólnienie stopnia pełnego w rdzeniu i w kolumnie sufiksalnej jest innowacją, a w sprawie pierwotnej struktury apofonicznej nominów na -es- odsyłam czytelnika do prac Schindler 1975 i Stüber 2002. 
Z tego wynika, że słow. kolo, kolese 'koło' nie odpowiada oczekiwanemu wzorowi i polega na przekształceniu starszej formacji ${ }^{\star} k o l-o$-, która formalnie zgadza się ze

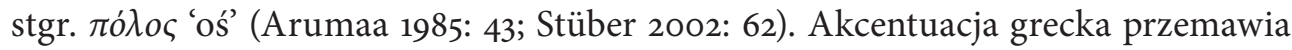
za starym nomen actionis 'obracanie' lub sekundarnie nomen acti 'obrót'. Wniosek: słow. kolěno to stary przymiotnik przynależnościowy, utworzony od rzeczownika, który odpowiadał etymologicznie słow. kolo, kolese 'koło' i być może stgr. đółos 'oś'. Przejdźmy do analizy materiału bałtyckiego.

Lit. kẽlis (2) / (dial.) kelỹs (2) i łot. celis 'kolano' kontynuują pbałt. ${ }^{\star} k e l-i j a-$. Obok kẽlis (2) / (dial.) kelỹs (2), poświadczonych już w starolitewskim, notuje się również w starolitewskiej Postylli Daukszy formę kẽlias (2) 'kolano; pokolenie' (dawny temat na -ja-). W litewskim obserwujemy więcej tego rodzaju dubletów, np. literackiemu élnias (1) 'jeleń' odpowiada stlit. élnis / elnỹs (2) 'jeleń', stlit./dial. mẽdžias (2) 'las; drzewo' odpowiada lit. mẽdis (2) 'drzewo', obok stlit. vãrias (2) 'miedź’ występuje nlit. vãris (2) (więcej przykładów podaje Otrębski 1965: 64-65). W przypadku takich dubletów jako tertium comparationis służy język łotewski. Na podstawie łot. mežs 'las' (<*med-ja-s) i varšs 'miedź' (<*var-ja-s) wnioskujemy o archaiczności lit. mẽdžias i vãrias w stosunku do literackich mẽdis i vãris. $\mathrm{Z}$ drugiej strony, $\mathrm{z}$ powodu łot. alnis 'łoś' i celis 'kolano' musimy przyjąć już dla prabałtyckiego istnienie przymiotników ${ }^{*}$ eln-ija-s oraz ${ }^{*} k e l-i j a-s$. Przekształcenie bałtyckiego sufiksu ${ }^{*}$-ija- w litewsko-łotewskie -i-l-i- jest wynikiem przekształceń morfo- i morfonologicznych, których opis wykracza poza ramy tego artykułu. Dla naszych celów ważne jest to, że na podstawie zgodnego świadectwa litewskiego kêlis (2) / (dial.) kelĩs (2) i łotewskiego celis 'kolano' możemy odtworzyć prabałtycki przymiotnik *kel-ija-s. Natomiast kẽlias (2) 'kolano; pokolenie' jest albo rezultatem działania analogii, albo substantywizowanym przymiotnikiem $\mathrm{z}$ ide. sufiksem posesywnym (dokładniej przynależnościowym) *-yo-, por. stgr. $\pi \dot{\alpha} \tau \rho \iota \iota,-\alpha,-o v$ 'ojczysty, ojcowski; pochodzący od ojca, przodków; odziedziczony; tradycyjny', łac. patrius 'ojcowski; dziedziczny', stind. pitrya- 'vät-

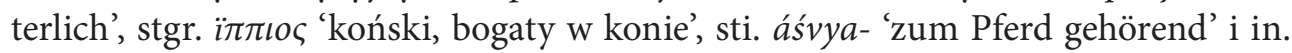
(Schwyzer 1990: 466), myk. qo-wi-ja /g'owiā/ 'imię bogini', po-ni-ki-jo /phoinikio/ 'gehörig zum Frucht des $\varphi$ ôेvı $\xi$; Palmdattel' (Heubeck 1985: 127), patronimika: stgr.

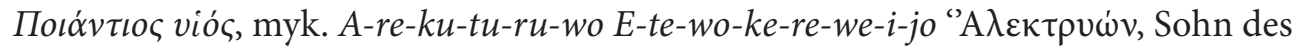

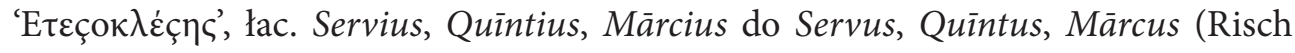
1974: 112).

Zwartą znaczeniowo i formalnie grupę tworzą substantywizowane przymiotniki litewskie na *-ija-, które oznaczały przynależność. Christian Stang (1966: 146), a za nim Rick Derksen (1996: 46) łączą je z wedyckim typem udaníya- 'watery' i greckim

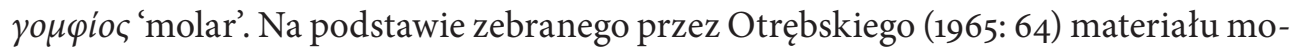
żemy stwierdzić, że derywaty przynależnościowe na ${ }^{*}-i j a-\left(\mathrm{fem} .{ }^{*}-i j a \bar{a}-=>-\dot{e}-\right)^{3}$ są two-

3 O pochodzeniu bałtyckich tematów na -ē- zob. Kuryłowicz 1966. 
rzone od rzeczowników i jeśli podstawa jest nieakutowana, wówczas derywat należy z reguły do drugiego paradygmatu akcentowego, a więc podobnie jak kẽlis (2) / (dial.) kelĩs (2). Przykłady:

vakaraĩ $\left(3^{\mathrm{b}}\right)$ 'zachód (strona świata)' $\rightarrow$ vakãris (2) 'wiatr zachodni', vãsara (1) 'lato' $\rightarrow$ vasãris (2) 'ciepły letni wiatr (z południa)', žiemà (4) 'zima' $\rightarrow$ žiẽmis (2) / žiemỹs (4) 'wiatr północny', vanduõ 'woda' $\rightarrow$ vandẽnis (2) 'wodnik', drãpana (1) 'bielizna, odzienie' $\rightarrow$ drapãne (2) 'pomieszczenie, szafa na bieliznę, odzienie', kãras (4) 'wojna' $\rightarrow$ kãris (2) 'wojsko, obóz wojskowy' / karỹs (4) 'żołnierz', pãkulos $\left(1,3^{\text {b }}\right)$ 'pakuły' $\rightarrow$ adj. pakùlis, - $\dot{e}(2)$ 'len wyglądający jak pakuły, koloru pakuł', pelenaĩ ( $3^{\mathrm{b}}$ ) 'popiół' $\rightarrow$ pelẽne (2) 'popielnik', sãmanos (1) 'mech' $\rightarrow$ samãne (2) 'dzika pszczoła'.

Niekiedy wciąż jest jeszcze widoczna ich funkcja przymiotnikowa, np. pakùliai linaĩ 'len wyglądający jak pakuły', samãnè bite 'dzika pszczoła' (ibid.). Stara funkcja atrybutywna interesującego nas leksemu jest jeszcze uchwytna we frazie keliai broliai 'rodzeni bracia' (dosł. 'kolanowi bracia') w cytowanym w części 2 przykładzie, gdzie keliai występuje w szyku przydawkowym do rzeczownika broliai 'bracia'. Jeśli podstawowy rzeczownik jest akutowany, wówczas istnieją dwie możliwości:

1) nastąpiła metatonia i derywat należy do (2) typu akcentowego: kiáušas $(1,3)$ 'czaszka, czerep' $\rightarrow$ kiaũšis (2) 'jajko', taukaĩ (3) [acc. pl. táukus] 'tłuszcz' $\rightarrow$ taũkis, $-\dot{e}(2)$ 'żywokost, Symphytum officinale',

2) derywat należy do (3) lub (4) paradygmatu akcentowego: rytã (3) 'wschód (strona świata)' $\rightarrow$ rytĩs (4) 'wiatr wschodni', árklas (3) 'radło' $\rightarrow$ arklỹs (3) 'koń'. Stan ten jest zapewne późniejszy wobec wcześniejszych przykładów z metatonią.

Na podstawie powyższych przykładów możemy zatem przyjąć, że lit. kẽlis (2) / (dial.) kelĩs (2) oraz łot. celis 'kolano' to stare przymiotniki „przynależnościowe” na *-ija-, utworzone od nomen pbałt. ${ }^{\star} k e l$-a- 'koło', zaświadczonego w stpr. kelan 'koło', łot. duceles 'dwukółka' i łot. cęls 'warstwa nici na kłębku' < *kelas (Karulis 1992: 162).

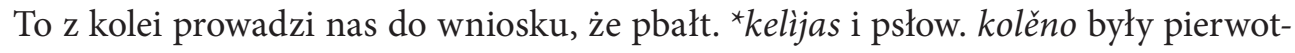
nie derywatami posesywnymi, utworzonymi od leksemów o znaczeniu 'koło'. Na tej podstawie możemy przyjąć, że znaczenie etymologiczne pbałt. ${ }^{\star} k e l i j a s$ i psłow. *kolěno to *'należący do obracającej się części ciała, dosł. kołowy' (ide. ${ }^{*} k^{w} e l h_{1}$ - 'obracać (się)').

\section{Skróty}

akad. - akadyjski; arum. - arumuński; chorw. - chorwacki; dial. - dialektalny; dosł. - dosłownie; fem. - femininum; germ. - germański; goc. - gocki; gw. - gwarowy; hol. - holenderski; ide. - indoeuropejski; irl. - irlandzki; lit. - litewski; łac. - łaciński; łot. - łotewski; myk. - mykeński; niem. - niemiecki; nlit. - nowolitewski, pbałt. - prabałtycki; pgerm. pragermański; pol. - polski; psłow. - prasłowiański; s-chorw. - serbo-chorwacki; scs. staro-cerkiewno-słowiański; słow. - słowiański; słoweń. - słoweński; sogd. - sogdyjski; stang. - staroangielski; stfr. - starofrancuski; stgr. - starogrecki; stind. - staroindyjski; 
stirl. - staroirlandzki; stisl. - staroislandzki; stlit. - starolitewski; stpr. - staropruski; strus. staroruski; stwysniem. - staro-wysoko-niemiecki; węg. - węgierski

\section{Teksty źródłowe i słowniki}

Baetke W., 2006, Wörterbuch zur altnordischen Prosaliteratur. Digital; vollständiges Faksimile der 1. Auflage (Berlin 1965-1968) zusammen mit Titelei und beiden Vorwörtern der zweiten, durchgesehenen Auflage (Darmstadt 1976) samt Korrekturen, erweitert um einen alphabetischen Stichwortindex aller im Wörterbuch verzeichneten altnordischen Wörter mit Flexions- und Wortklassenangaben, oprac. H. Fix, N. Endres, A. Schabalin, współpr. A. Braml, S. Holtzhauer, J. Ilgner, A.-K. Müller, F. Schwabe, Greifswald.

BlAISE A., 1975, Lexicon latinitatis medii aevi. Dictionnaire latin-français des auteurs du moyen âge, Turnholti.

Bosworth J., Northcote Toller T., 1898, An Anglo-Saxon Dictionary, Oxford, [on-line:] http://www.bosworthtoller.com/about.

DP: Postilla Catholicka. Tái est: Iźguldimas Ewangeliu kiekwienos Nedelos ir szwętes per wissús metús. Per Kúniga Mikaloiv Davkszą Kanonîką Médnikų... 1599, [w:] J. Palionis (red.), Mikalojaus Daukšos 1599 metu Postile ir jos šaltiniai, Vilnius 200o, s. 36-1303.

KARUlis K., 1992, Latviešu etimologijas vārdnīca divos sējumos, t. 1-2, Rīga.

Katkus M., 1931, Balanos Gadynè. Vaizdai iš netolimos praeities, „Mūsų Tautosaka” 4.

KöвlER G., 2014, Mittelniederdeutsches Wörterbuch, wyd. 3, [on-line:] http://www.koeblergerhard.de/mndwbhin.html.

LKŽ: K. Ulvydas (red.), Lietuvių kalbos žodynas, t. 12, Vilnius 1981.

Mažıulis V., 1993, Prūsų kalbos etimologijos žodynas, t. 2: I-K, Vilnius.

Niermeyer J.F., 1976, Mediae Latinitatis lexicon minus, Leiden.

RePGow E. von, 1861, Des Sachsenspiegels erster Theil, oder das sachsische Landrecht: nach der Berliner Handschrift v. J. 1369, Berlin.

SD 3: Dictionarium trium lingvarum. In usum Studiosae Iuventutis, avctore [...] Constantino Szyrwid... (1642), [w:] K. Pakalka, J. Kruopas, A. Lyberis, J. Marcinkevičius, A. Ivaškevičius (red.), Pirmasis lietuvių kalbos žodynas, Vilnius 1979, s. 95-658.

SP: Šyrwids Punktay sakimu (Punkty kazań). Teil I: 1629, Teil II: 1644; litauisch und polnisch, wstęp F. Specht, Göttingen 1929.

SPsı: F. Sławski (red.), Słownik prasłowiański, t. 2: C-Davbnota, Wrocław 1976, s. 95-658.

Sreznevskij I.I., 1893, Materialy dlja slovarja drevnerusskogo jazyka, t. 1: A-K, Sankt Peterburg.

\section{Literatura}

Aruma P., 1985, Urslavische Grammatik. Einführung in das vergleichende Studium der slavischen Sprachen, t. 3: Formenlehre, Heidelberg.

Benveniste É., 1927, Notes sogdiennes, „Mémoires de la Société de Linguistique” 27, s. 51-53.

BiaŁuński G., 2014, „Cognati” czy „agnati”? Przyczynek $w$ sprawie rodu u pogańskich Prusów, „Pruthenia” 9, s. 183-205. 
Casaretto A., 2004, Nominale Wortbildung der gotischen Sprache. Die Derivation der Substantive, Heidelberg.

Derksen R., 1996, Metatony in Baltic, Amsterdam - Atlanta.

ENDZELIN J., 1922, Lettische Grammatik, Riga.

Griepentrog W., 1995, Die Wurzelnomina des Germanischen und ihre Vorgeschichte, Innsbruck.

Gulczyński A., Lesiński B., WalaChowiCz J., Wiewionowski J., 2002, Historia państwa i prawa. Wybór tekstów źródłowych, wyd. 2 popr. i zm., Poznań.

Heubeck A., 1985, Zu den mykenischen Stoffadjektiven, „Münchener Studien zur Sprachwissenschaft" 46, s. 123-138.

KABAŠINSKAITĖ B., 2014, Etimologijos metmenys. Istorija - teorija - skaitiniai, Vilnius.

Kroonen G., 2013, Etymological Dictionary of Proto-Germanic, Leiden - Boston.

KuryŁowicz J., 1966, Bałtycka deklinacja na -ē-, „Acta Baltico-Slavica” 3, s. 83-88. Przedruk w: Les thémes en -ē- du Baltique, s. 418-425, [w:] idem, Esquisses linguistiques II, München 1975 .

Lотн J., 1917-1919, Notes étymologiques et lexicographiques, „Revue Celtique” 37, s. 65-69, 297-316.

Lотн J., 1923, Le mot désignant le genou au sens de génération chez les Celtes, les Germains, les Slaves, les Assyriens, „Revue Celtique” 40, s. 143-152.

OtręвSKI J., 1965, Gramatyka języka litewskiego, t. II: Nauka o budowie wyrazów, Warszawa.

PÂrvulescu A., 1997, 'Knee' and 'generation/people' in Indo-European: Lat. "poples” 'knee' vs. „populus" 'people' and parallels, „Indogermanische Forschungen” 102, s. 74-83, [on-line:] https://doi.org/10.1515/9783110243437.74.

Risch E., 1974, Wortbildung der homerischen Sprache, Berlin - New York.

SCHINDler J., 1975, Zum Ablaut der neutralen s-Stämme des Indogermanischen, [w:] H. Rix (red.), Flexion und Wortbildung. Akten der V. Fachtagung der Indogermanischen Gesellschaft. Regensburg, 9.-14. September 1973, Wiesbaden, s. $259-267$.

SchwyZer E., 1990, Griechische Grammatik. Erster Band. Allgemeiner Teil. Lautlehre. Wortbildung. Flexion, München.

SŁAWSKi F., 1974, Zarys słowotwórstwa prasłowiańskiego, [w:] idem (red.), Słownik prasłowiański, t. 1: $A-B$, Wrocław, s. 43-141.

StANG CH., 1966, Vergleichende Grammatik der Baltischen Sprachen, Oslo.

STÜBER K., 2002, Die primären s-Stämme des Indogermanischen, Wiesbaden.

\section{Why Did Balts and Slavs Count Kinship in Knees, or the Etymology of Slav. kolěno 'knee; tribe' and Lith. kẽlis 'knee; tribe' Summary}

OCS. kolěno 'knee; tribe, generation' (cf. Polish pokolenie 'generation') and Lith. kẽlis 'knee; joint in a plant; tribe; degree of kinship' come from old adjectives with possessive suffixes (-èn- in Slavic and -ija- in Baltic). Their primary meaning was 'a joint in the body' (*a rotating part of the body'). Both were formed from nouns with the meaning 'wheel' (OCS. kolo, kolese 'wheel', Old Prussian kelan 'wheel', Latvian duceles 'chaise'; IDE. ${ }^{*} k^{w} e l h_{1}-$ 'to turn, to rotate'). The hypothesis proposed in this paper explains the semantic relationship between Slav. kolèno 'knee; tribe, generation' and Proto-Slav. ${ }^{\star} k e l-n \breve{u}->{ }^{*} \check{c}$ lnŭ- > Slovenian člèn // Serbo-Croatian člân 'joint; ankle, talus'. Assuming that the 
meaning 'joint' was the original one, OCS. kolěno 'tribe, generation' and Lith. kẽlis 'degree in relationship; tribe' can be interpreted as old terms of customary law in the field of succession. The counting of kinship by enumeration of body parts from the head to the middle fingernail has been preserved in Middle Low German customary law, so-called "Sachsenspiegel". The hypothesis is supported by numerous parallels: Lith. sanarys 'a joint in the body; (OLith.) 'generation', Lith. stráipsnis 'body part; (OLith.) generation', OPr. streipstan 'body part; generation', Middle High German Gelied 'body part; generation', and Middle Low German lede 'a joint in the body; body part; degree of kinship'. 